\title{
Wlaściwości zapraw cementowych modyfikowanych wybranymi popiołami
}

\author{
Monika Bała, Monika Kukawska, Wojciech Piasta
}

\author{
Katedra Technologii i Organizacji Budownictwa, \\ Wydziat Budownictwa i Architektury, Politechnika Świętokrzyska, \\ e-mail:monika.bala91@gmail.com,monikalukawska@interia.pl,wpiasta@tu.kielce.pl
}

Streszczenie: W pracy przedstawiono wyniki badań składu chemicznego i wybranych właściwości popiołów lotnych krzemionkowych oraz popiołów pochodzących z utylizacji osadów ściekowych. Zaprezentowane w artykule wyniki badań dotyczą wpływu ww. popiołów na wybrane właściwości świeżych zapraw. Dokonano również identyfikacji faz krystalicznych, korzystając z analizy XRD. Za pomocą skaningowego mikroskopu elektronowego zauważono, iż ziarna popiołu krzemionkowego różnią się kształtem w porównaniu z ziarnami popiołu pochodzącego z utylizacji osadów ściekowych. Z kolei z obserwacji zapraw wynika, że faza C-S-H zaprawy z dodatkiem popiołu krzemionkowego i popiołu z osadów ściekowych jest dość zwarta. Wykonano także badanie wytrzymałości zapraw na ściskanie po 28 i 90 dniach dojrzewania.

Słowa kluczowe: popiół z utylizacji osadów ściekowych, popiół lotny krzemionkowy, skład chemiczny i fazowy, mikrostruktura zapraw, wytrzymałość na ściskanie.

\section{Wstęp}

Obecny rozwój wiedzy w zakresie materiałów budowlanych, w tym cementu, skłania do stosowania rozwiązań korzystnych zarówno pod względem ekonomicznym, jak również ekologicznym. Niewątpliwie zastosowanie dodatków do cementu lub betonu w postaci popiołów lotnych wpisuje się w strategię zrównoważonego rozwoju. Ich użyteczność pozwala na ograniczenie ilości klinkieru portlandzkiego potrzebnego do wytworzenia cementu, a co za tym idzie podczas produkcji obniża się zużycie energii oraz redukuje emisję $\mathrm{CO}_{2}$. Dużą zaletą stosowania popiołów lotnych jest również utylizacja produktów ubocznych powstających w wyniku procesów przemysłowych [1]. Właściwe wykorzystanie popiołów lotnych wpływa także na poprawę wybranych właściwości zapraw i betonów.

Zgodnie z normą PN-EN 450-1:2009 +A1 [2] popioły lotne są określane jako dodatek typu II do betonu. Istotną kwestię stanowi tutaj parametr jakościowy, którym jest wskaźnik aktywności, czyli stosunek procentowy wytrzymałości na ściskanie beleczek wykonanych wodpowiednich proporcjach cementu porównawczego i masy popiołu lotnego do wytrzymałości na ściskanie beleczek wykonanych z zaprawy normowej. Według normy wskaźnik aktywności po 28 dniach dojrzewania nie powinien być poniżej 75\% wytrzymałości zaprawy, natomiast po 90 dniach dojrzewania powinien osiągnąć minimum 85\% wytrzymałości na ściskanie wykonanej na cemencie porównawczym. Wykorzystany do badań cement porównawczy musi spełniać wymagania określone w normie PN-EN 197-1 [3]. Nierozstrzygniętą kwestią do tej pory pozostaje jednak możliwość stosowania popiołów pochodzących ze spalania osadów ściekowych, który nie 
został jeszcze w pełni zaakceptowany jako dodatek do cementu lub betonu [4]. Wysoka zawartość krzemionki w popiele z osadów ściekowych może wykazywać aktywność pucolanową, zachęcającą do zastosowania w betonie.

\subsection{Popioły lotne krzemionkowe}

Popiół lotny krzemionkowy powstaje jako produkt uboczny spalania węgla kamiennego w temperaturze $1300-1450^{\circ} \mathrm{C}$ w kotłach energetycznych. Jest drobnoziarnistym materiałem pylastym, jego ziarna mają kulisty kształt i gładką, szklistą powierzchnię [5]. O gęstości popiołu, która mieści się w granicach 2,1-2,4 g/ $\mathrm{cm}^{3}$, decyduje głównie jego skład chemiczny oraz uziarnienie, wpływające także na wodożądność popiołów lotnych[6],[7]. Istotny wpływ na właściwości pucolanowe popiołu krzemionkowego ma budowa fazy szklistej i skład ziarnowy. Do głównych składników popiołu należą dwutlenek krzemu $\mathrm{SiO}_{2}$ oraz tlenek glinu $\mathrm{Al}_{2} \mathrm{O}_{3}$. W mniejszych ilościach występuje także tlenek żelaza $\mathrm{Fe}_{2} \mathrm{O}_{3}$ [8]. Zastosowanie popiołu krzemionkowego jako dodatku do cementu niesie ze sobą szereg zalet. Do najważniejszych należy zaliczyć: opóźniony początek wiązania zaczynu, właściwą urabialność mieszanki betonowej, wysoką odporność na działanie czynników korozyjnych oraz bardzo dobre parametry wytrzymałościowe [7].

\subsection{Popiół z utylizacji osadów ściekowych}

Osady ściekowe są produktami ubocznymi technologii oczyszczania ścieków. Utylizacja osadów ściekowych związana jest z suszeniem i spalaniem, w wyniku którego powstaje popiół. Produkt może znaleźć zastosowanie jako dodatek do betonu lub cementu [9], [10]. Należy jednak pamiętać, że popiół z utylizacji osadów ściekowych musi spełniać kryteria zawarte w normie PN-EN 450-1+A1 2009 [2], która dopuszcza stosowanie popiołu pochodzącego ze współspalania pyłu węglowego z materiałami roślinnymi, drewnem, odpadami zwierzęcymi, osadami ze ścieków komunalnych. Literatura podaje, że możliwe jest dodanie $20 \%$ popiołu do cementu [10]. W przypadku użycia popiołu z utylizacji osadów ściekowych jako składnika zastępującego część klinkieru portlandzkiego w cemencie należy wziąć pod uwagę aktywność pucolanową, która wynika ze składu chemicznego i mineralnego. Popioły te charakteryzują się różnym i zmiennym składem, zależącym od rodzaju ścieków oraz sposobu ich oczyszczania i utylizacji. W praktyce wpływ składu chemicznego widoczny jest przede wszystkim w opóźnionym przyroście wytrzymałości [11]. Nie do końca jednak wyjaśniony został długoterminowy rozwój wytrzymałości, który może być jednym z czynników decydujących o przydatności popiołów z utylizacji sadów ściekowych do spoiw cementowych. Powolne narastanie wytrzymałości betonów może wynikać z dużej ilości związków fosforu w popiołach z osadów ściekowych. Obecność jonów fosforanowych w zaczynie cementowym może opóźniać proces hydratacji i twardnienia [12].

\section{Materiały do badań}

W badaniach własnych został wykorzystany cement portlandzki CEM I 42,5, popiół krzemionkowy (FA), popiół z utylizacji osadów ściekowych (SSA) z komunalnej oczyszczalni ścieków oraz kruszywo naturalne (piasek). Wszystkie badania zostały przeprowadzane zaprawach, w których stosunek wagowy składników spoiwo : piasek : woda był stały i wynosił 1:3:0,55. Wykonano zaprawy, w których część cementu portlandzkiego zastąpiono popiołem krzemionkowym bądź popiołem z utylizacji ściekowych. Poza tym doświadczenie obejmowało także wykonanie zaprawy kontrolnej, zawierającej jedynie cement 
portlandzki. W poniższej tabeli (Tab. 1) przedstawiono procentowe zawartości cementu portlandzkiego i popiołów w spoiwie w analizowanych zaprawach.

Tabela 1. Skład procentowy spoiwa analizowanych zapraw

\begin{tabular}{cccc}
\hline \multirow{2}{*}{$\begin{array}{c}\text { Oznaczenie serii } \\
\text { zaprawy }\end{array}$} & \multicolumn{2}{c}{ Zawartość [\%] } \\
\cline { 2 - 4 } & cement portlandzki & popiół krzemionkowy & $\begin{array}{c}\text { popiół z utylizacji } \\
\text { osadów ściekowych }\end{array}$ \\
\hline CEM I & 100 & 0 & 0 \\
\hline FA 10 & 90 & 10 & 0 \\
\hline FA 20 & 80 & 20 & 0 \\
\hline SSA 10 & 90 & 0 & 10 \\
\hline SSA 20 & 80 & 0 & 20 \\
\hline
\end{tabular}

\section{Metody badań}

Plan badań obejmował 5 serii zapraw, które zostały wykonane zgodnie z ujednoliconą procedurą dozowania, mieszania i formowania próbek. Badanie świeżych zapraw obejmowało oznaczanie konsystencji według PN-EN 1015-3:2000 [13], gęstości objętościowej oraz zawartości powietrza metodą ciśnieniową zgodnie z PN-EN 12350-7:2011 [14]. Ocenę wytrzymałości na ściskanie wykonano na beleczkach w kształcie prostopadłościanu o wymiarach 40 x 40 x 160 mm w oparciu o normę PN-EN 196-1:2006 [15]. Bezpośrednio po przygotowaniu zaprawy uformowano beleczki, które zostały rozformowane po 24 godzinach. Następnie umieszczono je w wodzie o temperaturze $20 \pm 1{ }^{\circ} \mathrm{C}$, na rusztach, co zapewniło swobodny dostęp wody do całej powierzchni próbek. Beleczki przebywały w wodzie do czasu badania wytrzymałości, które wykonano po 28 i 90 dniach na połówkach beleczek.

Metodyka badań obejmowała również określenie składu chemicznego za pomocą WDXRF oraz identyfikację faz krystalicznych wykorzystując do tego analizę rentgenowską XRD. Poza tym skorzystano ze skaningowej analizy mikroskopowej razem z analizą w mikroobszarach (SEM-EDS), dzięki którym zaobserwowano mikrostrukturę zapraw cementowo-popiołowych oraz identyfikację pierwiastków chemicznych wchodzących w ich skład.

\section{Wyniki badań}

\subsection{Skład chemiczny i mikrostruktura popiołów}

Wyniki badań składu chemicznego popiołu z osadów ściekowych (SSA) zostały przedstawione w Tab. 2. Poza podstawowymi składnikami ( $\left.\mathrm{CaO}, \mathrm{SiO}_{2}, \mathrm{Al}_{2} \mathrm{O}_{3}\right)$, zaobserwowano znaczącą zawartość fosforu oraz niewielką zawartości metali (Tab. 3), które nie zagrażają bezpieczeństwu zastosowania do zapraw i betonów

Tabela 2. Skład chemiczny popiołu z osadów ściekowych

\begin{tabular}{ccccccccccc}
\hline Składnik & $\mathrm{SiO}_{2}$ & $\mathrm{Al}_{2} \mathrm{O}_{3}$ & $\mathrm{Fe}_{2} \mathrm{O}_{3}$ & $\mathrm{CaO}$ & $\mathrm{MgO}$ & $\mathrm{SO}_{3}$ & $\mathrm{Cl}-$ & $\mathrm{P}_{2} \mathrm{O}_{5}$ & $\mathrm{Na}_{2} \mathrm{O}$ & $\mathrm{K}_{2} \mathrm{O}$ \\
\hline Zawartość [\%] & 16,60 & 5,10 & 9,10 & 12,90 & 3,80 & 2,10 & 0,01 & 15,00 & 3,50 & 2,80 \\
\hline
\end{tabular}

Tabela 3. Zawartość metali w popiele z osadów ściekowych

\begin{tabular}{ccccccccc}
\hline Pierwiastek & $\mathrm{Cr}$ & $\mathrm{Mn}$ & $\mathrm{Cu}$ & $\mathrm{Ni}$ & $\mathrm{Zn}$ & $\mathrm{Ba}$ & $\mathrm{Pb}$ & $\mathrm{Sn}$ \\
\hline Zawartość [\%] & 0,02 & 0,07 & 0,06 & 0,01 & 0,30 & 0,09 & 0,01 & 0,01 \\
\hline
\end{tabular}


Do składników chemicznych popiołów krzemionkowych (Tab.4.) należy zaliczyć: $\mathrm{SiO}_{2} \mathrm{Al}_{2} \mathrm{O}_{3}, \mathrm{Fe}_{2} \mathrm{O}_{3}, \mathrm{CaO}, \mathrm{MgO}, \mathrm{SO}_{3}$, pochodzące $\mathrm{z}$ rozkładu minerałów ilastych, pirytu i kalcytu, które są składnikami nieorganicznymi węgli [16].

Tabela 4. Skład chemiczny popiołu krzemionkowego

\begin{tabular}{ccccccccc}
\hline Składnik & $\mathrm{SiO}_{2}$ & $\mathrm{Al}_{2} \mathrm{O}_{3}$ & $\mathrm{Fe}_{2} \mathrm{O}_{3}$ & $\mathrm{CaO}$ & $\mathrm{MgO}$ & $\mathrm{SO}_{3}$ & $\mathrm{Cl}-$ & $\mathrm{Na}_{2} \mathrm{O}_{\text {eq }}$ \\
\hline Zawartość [\%] & 50,50 & 26,10 & 7,40 & 4,50 & 2,90 & 0,50 & 0,01 & nie oznaczono \\
\hline
\end{tabular}

Składy fazowe popiołu krzemionkowego oraz popiołu z utylizacji osadów ściekowych zostały przedstawione na Rys. 1. oraz Rys.2.

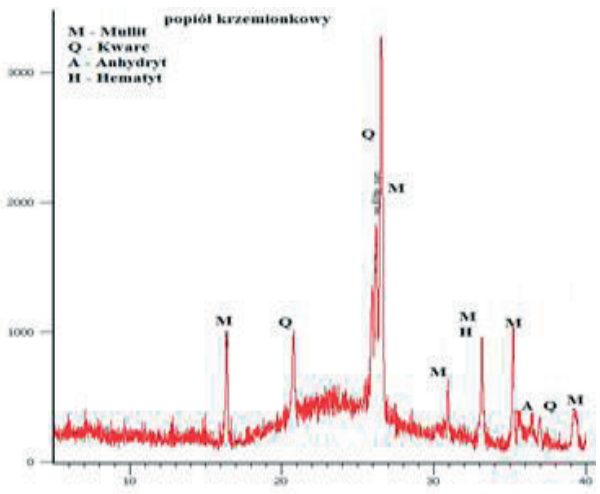

Rys. 1. Skład fazowy popiołu lotnego krzemionko- Rys. 2. wego.

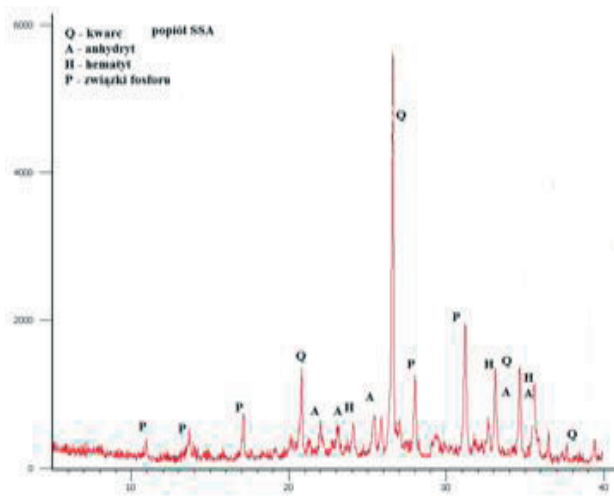

Dyfraktogram
ściekowych

Główne fazy krystaliczne w popiele krzemionkowym to: kwarc, hematyt, mulit i anhydryt. Pozostałe fazy są bezpostaciowe lub występują w niewielkiej ilości i nie są wykrywalne podczas analizy XRD. Z kolei w popiele z osadów ściekowych zidentyfikowano takie fazy jak kwarc, hematyt, anhydryt a także fazy zawierające fosfor. Łatwo zauważyć, że kwarc, hematyt i anhydryt występują w obu popiołach. Mulit występuje jedynie w popiele krzemionkowym, a związki fosforu tylko w popiele z utylizacji osadów ściekowych.

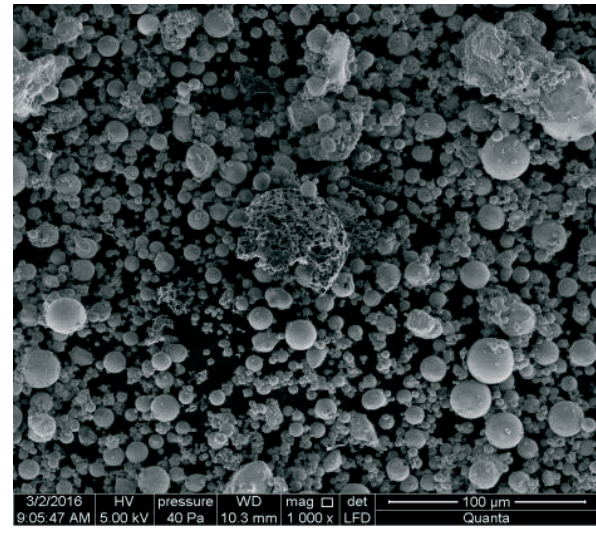

Rys. 3. Mikrostruktura popiołu krzemionkowego

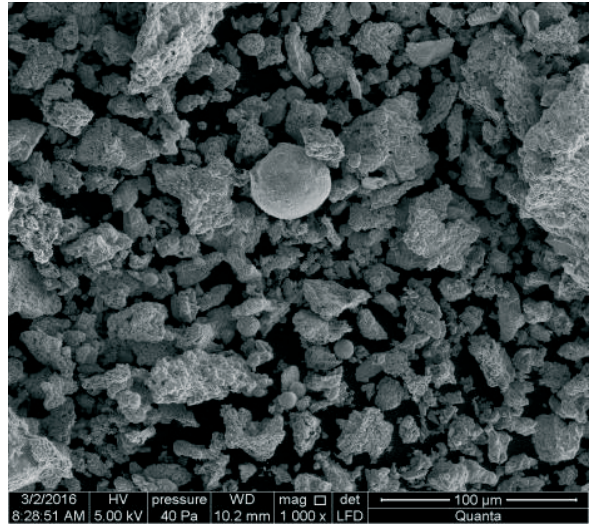

Rys. 4. Mikrostruktura popiołu z utylizacji osadów ściekowych 
W popiele krzemionkowym (Rys.3) występują przede wszystkim regularne ziarna o kształcie kul i gładniej powierzchni. Natomiast kształt ziaren popiołu z utylizacji osadów ściekowych (Rys.4) jest w głównej mierze nieregularny, a ziaren o gładkiej powierzchni jest znacznie mniej.

\subsection{Badania świeżych zapraw}

Oznaczenie konsystencji zapraw, ich gęstość objętościowa oraz zawartość powietrza zostały przedstawione w poniższej tabeli (Tab.5).

Tabela 5. Wyniki wybranych badań świeżych zapraw cementowo-popiołowych.

\begin{tabular}{cccc}
\hline Oznaczenie serii zapraw & $\begin{array}{c}\text { Średnica rozpływu } \\
{[\mathrm{cm}]}\end{array}$ & $\begin{array}{c}\text { Gęstość objętościowa } \\
{\left[\mathrm{kg} / \mathrm{m}^{3}\right]}\end{array}$ & $\begin{array}{c}\text { Zawartość powietrza } \\
{[\%]}\end{array}$ \\
\hline CEM I & 13,5 & 2160,0 & 5,2 \\
\hline V 10 & 14,0 & 2097,1 & 8,0 \\
\hline V 20 & 15,0 & 2064,4 & 8,0 \\
\hline SSA 10 & 13,0 & 1937,7 & 13,0 \\
\hline SSA 20 & 10,5 & 1892,5 & 10,0 \\
\hline
\end{tabular}

Dodatek popiołu krzemionkowego sprawił, że średnica rozpływu nieznacznie zwiększyła się o $0,5 \mathrm{~cm}$ w przypadku $10 \%$ zawartości popiołu i $1,5 \mathrm{~cm}$ dla $20 \%$ zawartości popiołu w porównaniu do zaprawy z cementu portlandzkiego. Inaczej było w przypadku popiołu z osadów ściekowych, gdzie średnica rozpływu była mniejsza niż dla zaprawy z cementu portlandzkiego, odpowiednio o 0,5 i $3 \mathrm{~cm}$ dla dodatku $10 \%$ i $20 \%$ popiołu. W przypadku wszystkich zapraw $\mathrm{z}$ dodatkami gęstość objętościowa $\mathrm{W}$ porównaniu do zaprawy kontrolnej zmniejszała się. Im więcej cementu zostało zastąpione popiołem, tym mniejszą gęstość objętościową zaprawy uzyskano. Zawartość powietrza w zaprawie cementowej wyniosła $5,2 \%$. W zaprawie $\mathrm{z}$ popiołem krzemionkowym, niezależnie od ilości dodatku powietrze stanowiło $8 \%$. Znacznie wyższą zawartość powietrza otrzymano dla zapraw modyfikowanych popiołem z osadów ściekowych. Dodatek w ilości $10 \%$ tego popiołu spowodował, że zawartość powietrza wyniosła aż 13\%, dla $20 \%$ popiołu była niższa, ponieważ kształtowała się w granicach $10 \%$ powietrza, jednak była prawie dwukrotnie wyższa niż dla zaprawy z cementu portlandzkiego. Prawdopodobnie dość duża zawartość powietrza związana jest $\mathrm{z}$ nieregularną budową i rozwiniętą powierzchnią ziaren popiołów z utylizacji popiołów ściekowych.

\subsection{Mikrostruktura zapraw cementowych modyfikowanych popiołami}

Wybrane wyniki skaningowej analizy mikroskopowej oraz analizy w mikroobszarach EDS zostały przedstawione na poniższych rysunkach (Rys. 3-7). W analizie zaprawy z cementu portlandzkiego (Rys.5) zaobserwowano nieregularną, zwartą fazę C-S-H. Dodatkowo zaobserwowano kryształy portlandytu, co potwierdziła analiza EDS.

Kolejne obrazy ukazują mikrostruktury zapraw cementowych modyfikowanych popiołami: krzemionkowym (Rys.6) oraz popiołem z osadów ściekowych (Rys.7), która różni się od mikrostruktury zapraw wykonanych wyłącznie z cementu portlandzkiego. Na Rys. 6a widoczne jest ziarno popiołu lotnego krzemionkowego, dla którego została wykonana również analiza EDS. Obserwacja zapraw z zawartością 20\% popiołu lotnego krzemionkowego (rys. 6b) przedstawia żel C-S-H oraz ziarna popiołu. W zaprawie z dodatkiem popiołu z osadów ściekowych zaobserwowano włóknistą formę fazy C-S-H (Rys. 7a i 7b). 

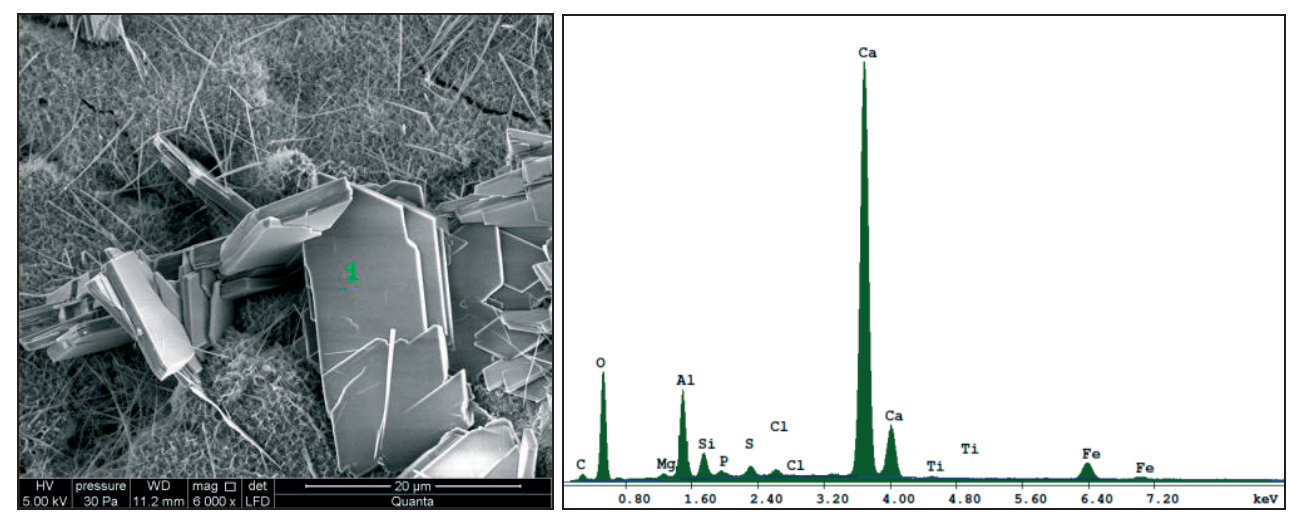

Rys. 5. Mikrostruktura zaprawy cementowej bez dodatków wraz z analizą EDS w zaznaczonym punkcie.
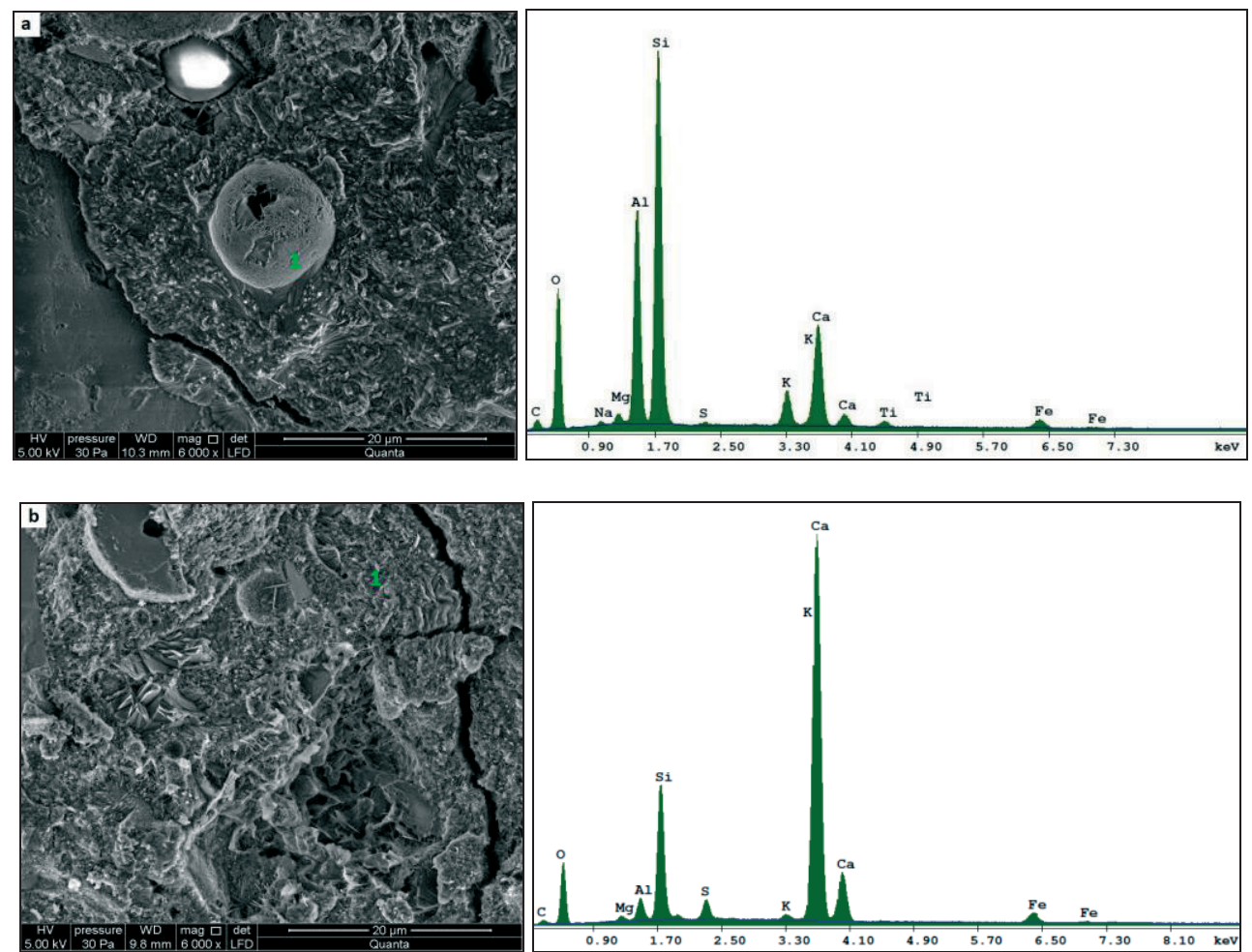

Rys. 6. Mikrostruktura zapraw cementowych z dodatkiem 10\% (rys.6a) oraz $20 \%$ (rys. 6b) popiołu lotnego krzemionkowego wraz z analizą EDS w zaznaczonych punktach. 

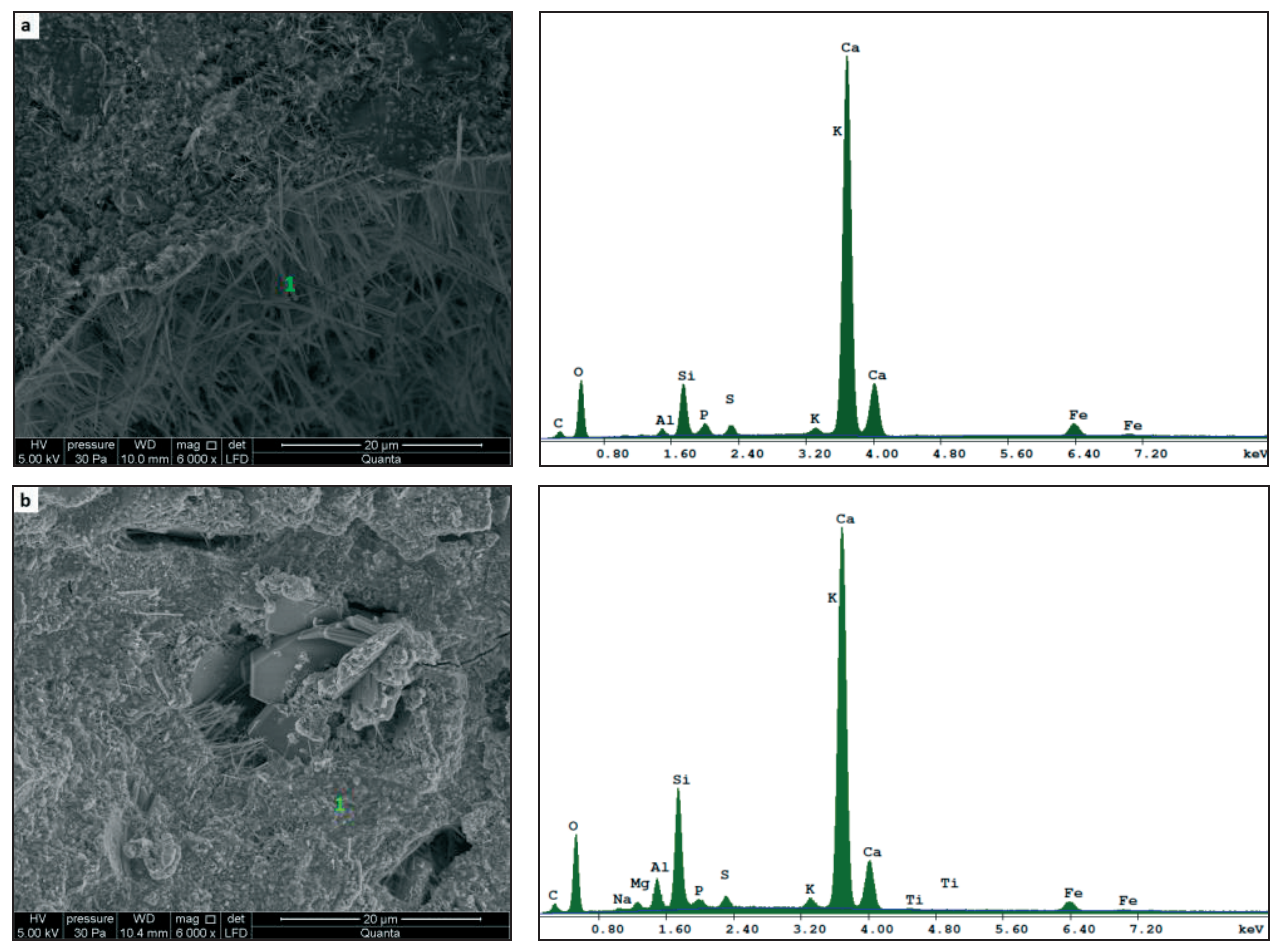

Rys. 7. Mikrostruktura zapraw cementowych z dodatkiem 10\% (rys. 7a) oraz 20\% (rys. 7b) popiołu z utylizacji osadów ściekowych wraz z analizą EDS w zaznaczonych punktach.

\subsection{Wytrzymałość na ściskanie}

Badanie wytrzymałości na ściskanie wykonano po 28 i 90 dniach dojrzewania (Rys. 8. i Rys. 9.). W obu przypadkach zaprawy z dodatkiem popiołu po 28 dniach osiągnęły niższe wytrzymałości niż zaprawy kontrolne wykonane wyłącznie z cementu portlandzkiego.

Na podstawie uzyskanych wyników można stwierdzić, że dodatek popiołu z osadów ściekowych powoduje wolniejszy przyrost wytrzymałości w porównaniu do zapraw z popiołem krzemionkowym. Spowodowane jest to wysoką zawartością jonów fosforanowych, w wyniku czego następuje znaczne spowolnienie hydratacji oraz obniżenie wytrzymałości wczesnych [16]. Zaobserwowano również od 28 do 90 dni znaczny przyrost wytrzymałości dla wszystkich serii z dodatkiem popiołów, zarówno w ilości 10\%, jak i 20\%.

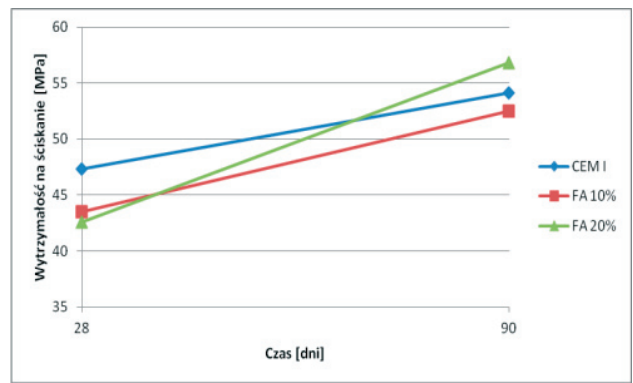

Rys. 8. Średnia wytrzymałość na ściskanie zapraw cementowych z popiołem krzemionkowym (FA) po 28 i 90 dniach dojrzewania. 


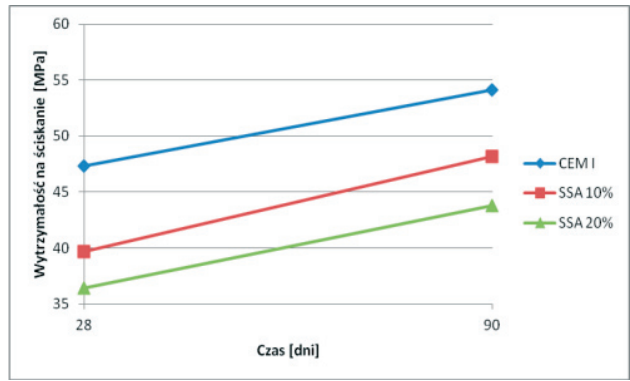

Rys. 9. Średnia wytrzymałość na ściskanie zapraw cementowych z popiołem z osadów ściekowych (SSA) po 28 i 90 dniach dojrzewania.

\section{Analiza i dyskusja wyników}

Na podstawie badań świeżych zapraw można zaobserwować korzystny wpływ dodatku popiołu lotnego krzemionkowego na urabialność, badaną na podstawie zmian rozpływu. Wpływ ten związany jest z kulistym kształtem ziaren popiołu, z których większość stanowią pełne kule, ale spotykane są także ziarna puste w środku. [6]. Z kolei dodatek popiołu z osadów ściekowych powoduje zmniejszenie urabialności świeżej zaprawy. Prawdopodobnie wynika to $\mathrm{z}$ nieregularnej budowy ziaren tego popiołu, a także dużej wodożądności cząstek o znacznej powierzchni [10]. Kształt i budowa ziaren wpływają również na różnice w gęstościach objętościowych oraz zawartości powietrza badanych zapraw.

Badania składu chemicznego popiołu krzemionkowego i popiołu z osadów ściekowych wykazały, że w ich składach występują znaczące różnice. Zawartość tlenku krzemu $\left(\mathrm{SiO}_{2}\right)$ w popiele $\mathrm{z}$ osadów ściekowych kształtowała się w granicach $16,6 \%$ i była zdecydowanie niższa niż w przypadku popiołu lotnego krzemionkowego, gdzie wyniosła blisko $50,5 \%$. Ilość tlenku glinu $\left(\mathrm{Al}_{2} \mathrm{O}_{3}\right)$ w SSA to 5,1\% zaś w FA $16 \%$. Natomiast ilość tlenku wapnia $(\mathrm{CaO})$ wyniosła odpowiednio $12,9 \%$ dla popiołu z osadów ściekowych oraz 4,5\% dla popiołu lotnego krzemionkowego.

Należy podkreślić, że w popiele z osadów ściekowych występują związki fosforu, których nie wykryto w popiele krzemionkowym. Ponadto SSA zawiera śladowe ilości metali ciężkich. Na podstawie rozpoznania faz krystalicznych za pomocą dyfraktometrii rentgenowskiej (Rys. 1 oraz Rys.2) stwierdzono zawartość kwarcu, hematytu i anhydrytu dla obu popiołów.

Różnice mikrostruktury między zaprawą kontrolną z cementu portlandzkiego, a zaprawami z popiołem lotnym krzemionkowym i popiołem z osadów ściekowych najbardziej widać w budowie fazy C-S-H. Obserwacje skaningowym mikroskopem elektronowym wykazały, że faza C-S-H w przypadku zapraw cementowych jest relatywnie nieregularna i zwarta. Z kolei na mikrofotografii zapraw modyfikowanych popiołami krzemionkowymi zaobserwowano nieprzereagowane ziarna, co powoduje efekt uszczelniający. To z kolei utrudnia dyfuzję i oddziaływanie czynników agresywnych. W mikrostrukturze zapraw z popiołem pochodzącym z osadów ściekowych zaobserwowano zwartą fazę C-S-H i brak dużych porów, co może wynikać z faktu, iż pory zostały wypełnione produktami reakcji pucolanowej [16].

Zaprawy zawierające $10 \%$ i $20 \%$ popiołu z osadów ściekowych miały niższą wytrzymałość na ściskanie niż zaprawa $\mathrm{z}$ cementu portlandzkiego. Różnice w wytrzymałości spowodowane są spowolnieniem reakcji pucolanowej m.in. ze względu na zawartość 
w popiele z osadów ściekowych związków fosforu [10]. Zaprawy z dodatkiem 10\% i 20\% lotnego popiołu krzemionkowego miały niższą wytrzymałość po 28 dniach dojrzewania, natomiast po 90 dniach osiągnęły wyższą wytrzymałość.

\section{Wnioski}

1. Podwyższona trwałość zapraw z dodatkiem popiołów: lotnego krzemionkowego oraz z utylizacji osadów ściekowych jest spowodowana przede wszystkim z odpowiedniej mikrostruktury tych zapraw, a także uzyskania określonych wytrzymałości na ściskanie, porównywalnych z zaprawami wykonanymi z cementu portlandzkiego.

2. Wpływ popiołu lotnego krzemionkowego i popiołu z osadów ściekowych na właściwości świeżych zapraw wynika z budowy ziaren obu popiołów. Popiół krzemionkowy poprawia urabialność mieszanki, a dodatek popiołu z osadów ściekowych zmniejsza.

3. Przyrost wytrzymałości zapraw z cementu zawierającego $10 \%$ i $20 \%$ popiołu z utylizacji osadów ściekowych był powolniejszy niż zaprawy z cementu portlandzkiego. Przyrost wytrzymałości między 28 a 90 dniem zaprawy z dodatkiem popiołu krzemionkowego był większy niż zaprawy popiołem z osadów ściekowych.

4. Niska zawartość metali oraz odpowiednia aktywność pucolanowa popiołu z osadów ściekowych pozwala na wykorzystanie go do zapraw i betonów w ilości nieprzekraczającej $20 \%$.

\section{Literatura}

1. Giergiczny Z. Popiót lotny składnikiem betonu - normalizacja i praktyka. Budownictwo Technologie Architektura, styczeń - marzec 2009.

2. PN-EN 450-1:2009 +A1 2009 Popiót lotny do betonu- część 1, Definicje, specyfikacje i kryteria zgodności.

3. PN-EN 197-1:2012 Cement - Część 1:Skład, wymagania i kryteria zgodności dotyczace cementów powszechnego użytku.

4. $\quad$ Smol M., Kulczycka J., Henclik A., Gorazda K.,Wzorek Z., 2015, The possible use of sewage sludge ash (SSA) in the construction industry as a way towards a circular economy, Journal of Cleaner Production, 95,45-54.

5. Kurdowski W., Chemia cementu i betonu, Wydawnictwo Naukowe PWN, Warszawa 2012.

6. Neville A.M. Właściwości betonu. Polski Cement, Kraków 2012.

7. Zapotoczna-Sytek G. Łaskawiec K., Gębarowski K., Małolepszy P., Szymczak J., Popioły lotne nowej generacji do produkcji autoklawizowanego betonu komórkowego, Warszawa 2013.

8. Giergiczny Z. Popiót lotny w składzie cementu i betonu. Wydawnictwo Politechniki Śląskiej Gliwice 2013.

9. Kosior-Kazberuk M. Karwowska J., Wybrane problemy zagospodarowania popiołów pochodzacych ze spalania osadów ściekowych $w$ technologii materiatów cementowych, Inżynieria Ekologiczna Nr 25,2011.

10. Kosior-Kazberuk M., Nowe dodatki mineralne do betonu. Budownictwo i Inżynieria Środowiska 2/2011.

11. Lynn C.J, Dhir R. K., Ghataora G.S., West R. P., Sewage sludge ash characteristics and potential for use in concrete, Construction and Building Material, 98, 767-779, 2015.

12. Małolepszy J., Tkaczewska E., Wpływ popiołów lotnych ze wspótspalania węgla kamiennego i biomasy na proces hydratacji i właściwości cementu. Materiały konferencji Dni Betonu. Wisła 2006, 591-601.

13. PN-EN 1015-3:2000 Metody badań zapraw do murów - Określenie konsystencji świeżej zaprawy (za pomoca stolika rozplywu). 
14. PN-EN 12350-7:2011 Badania mieszanki betonowej - Czesść 7: Badanie zawartości powietrza Metody ciśnieniowe.

15. PN-EN 196-1:2006 Metody badania cementu -- Część 1: Oznaczanie wytrzymałości.

16. Giergiczny Z., Właściwości popiołu lotnego a trwałość betonu, Budownictwo Technologie Architektura, lipiec-wrzesień 2007.

\title{
Properties of cement mortars modified by selected ashes
}

\author{
Monika Bała, Monika Lukawska, Wojciech Piasta \\ Kielce University of Technology, Department of Civil Engineering and Architecture, \\ Al. Tysiaclecia Państwa Polskiego 7, 25-314, Kielce, Poland, \\ e-mail:monika.bala91@gmail.com,monikalukawska@interia.pl,wpiasta@tu.kielce.pl
}

\begin{abstract}
The article presents the results of chemical composition and selected properties of the fly ash (FA) and sewage sludge ash (SSA) from the disposal of sewage sludge. The results of research on sewage sludge ash (SSA) and fly ash (FA) and the effect of these ashes on properties of fresh pastes have been presented. By means of XRD analysis, the occurrence of crystalline materials was detected. By means of SEM the morphology of ashes and cement pastes with ashes was investigated. The phase of the C-S-H mortars with addition of sewage sludge ash and fly ash is fairly compact. They performed the testing of compressive strength of mortars after 28 and 90 days of maturation.

Keywords: sewage sludge ash, fly ash, chemical and mineral composition, microstructure of mortars, compressive strength.
\end{abstract}

